\title{
A Study on the Distribution of Inorganic P Fractions in Soils of Low and High Available Phosphorus through a Laboratory Incubation Experiment
}

\author{
C. Jemila ${ }^{1 *}$, B. Bakiyathu Saliha ${ }^{2}$ and S.Udayakumar ${ }^{1}$ \\ ${ }^{1}$ Department of Soils Science and Agricultural Chemistry, Tamil Nadu Agricultural University, \\ Coimbatore-641003, Tami Nadu, India \\ ${ }^{2}$ Agricultural Research Station, Aruppukottai-626 107, Virudhunagar District, Tamil Nadu, India \\ *Corresponding author:
}

\section{A B S T R A C T}

\begin{tabular}{|l|}
\hline Ke y w o r d s \\
Phosphorus, \\
$\begin{array}{l}\text { Inorganic fractions, } \\
\text { Incubation, Release } \\
\text { pattern, Mussoorie } \\
\text { rock phosphate. }\end{array}$ \\
\hline Article Info \\
\hline $\begin{array}{l}\text { Accepted: } \\
\text { 18 February } 2017 \\
\text { Available Online: } \\
\text { 10 March } 2017\end{array}$ \\
\hline
\end{tabular}

\begin{abstract}
A laboratory incubation experiment was conducted during 2013-14 in the post graduate research laboratory of the Department of Soils and Environment at Agricultural College and Research Institute, Madurai to characterize the predominant rice growing soils of Vadipatti block of Madurai district into low and high $\mathrm{P}$ availability and to study the phosphorus release pattern and inorganic fractions of phosphorus. The treatments were imposed based on the fertiliser recommendation viz., 150:50:50 Kg N, $\mathrm{P}_{2} \mathrm{O}_{5}, \mathrm{~K}_{2} \mathrm{O}$ ha $^{-1}$, Mussoorie rock phosphate@ $224 \mathrm{~kg} \mathrm{ha}^{-1}$, farm yard manure @ 12.5 tonnes ha ${ }^{-1}$ and phosphate solubilizing bacteria (Lignite based phosphate solubilizing bacterium, Bacillus megateriumvar. Phosphaticum PSB-1) @ $2 \mathrm{~kg} \mathrm{ha}^{-1}$ in a Completely Randomized Design (CRD). A significant improvement in available $\mathrm{P}$ status was noticed with inoculation of $\mathrm{P}$ solubilizing bacteria with Mussoorie Rock Phosphate in soils of low and high available P status and the distribution pattern of inorganic fractions at the pre and post incubation period in the soils followed the pattern of Fe-P $>$ Al-P $>$ Ca-P $>$ Saloid-P $>$ Red-P and decreased gradually during the course of incubation period irrespective of the fractions.
\end{abstract}

\section{Introduction}

Phosphorus availability from soil is considered as a major constraint for crop production particularly in calcareous soils (Dange et al., 2008). These soils have extremely high capacity to precipitate phosphorus and thus its deficiency becomes wide spread inspite of high total phosphorus content in soil making it unavailable to plants. $P$ fixation tends to be more pronounced in clays if they are predominant with $\mathrm{CaO}$ and $\mathrm{CaCO}_{3}$. However organic manures and biofertilisers play an important role in improving the productivity of soils.
It is also estimated that crop can often utilise only one quarter to one third of applied fertiliser P during the first growing season and the next remain in soil as the equilibrium solution $\mathrm{P}$ concentration seldom exceeds 0.1 micro gram (Tandon, 1987). It is important to utilise and recycle native $\mathrm{P}$ for plant nutrition both to reduce the cost of production and sustain the mineral reserves for longer period. Management of soil $\mathrm{P}$ in intensive irrigated rice has rather received less attention than intensive cropping intensity and new cultivars, irrigation and fertiliser N. In early years crop response to fertiliser $\mathrm{P}$ were marginal (De Datta and Mikelsen, 1985). 
With continuous intensive cropping, $\mathrm{P}$ became the first deficient nutrient as revealed in long term experiments. Various biological and biochemical approaches have been tried past but ended up with limited success only. Moreover, the availability and uptake of phosphorus is generally influenced by soil properties and degree of soluble forms of phosphorus.

In the context of evaluating and enhancing the phosphorus use efficiency of different phosphatic fertilisers on rice crop yield, a better predictive understanding of $\mathrm{P}$ sorption and release behaviour of soils is needed. In particular, more information on the rate and amount of desorption of inorganic $\mathrm{P}$ from different soils, would be useful in adopting the suitable $\mathrm{P}$ management practices under different soil - crop - environment situations. With this background in view, the $\mathrm{P}$ release pattern of the major rice growing soils were assessed through laboratory incubation study followed by a field trial laid out in the Irumbadi village of Vadipatti block in Madurai district and standardised the best $\mathrm{P}$ management practice for enhancing the $\mathrm{P}$ use efficiency and maximizing the rice crop yield. The results of the incubation experiment details are furnished below.

\section{Materials and Methods}

Incubation experiment was conducted in the post graduate research laboratory of the Department of Soils and Environment at Agricultural College and Research Institute, Madurai for a period of 60 days. The predominant rice growing tract of Madurai district was chosen to study the $\mathrm{P}$ distribution in soils. Representative surface $(0-15)$ soil samples from 26 villages of Vadipatti block were collected, processed and analysed for the status of $\mathrm{P}$ availability. Based on the analytical results, these soils were categorized into low $\left(<11 \mathrm{~kg} \mathrm{ha}^{-1}\right)$ and high $\left(>22 \mathrm{~kg} \mathrm{ha}^{-1}\right)$ status of $\mathrm{P}$ availability. Details of the location of collection and categorization of soil samples for conducting the laboratory incubation study are furnished in tables 1 and 2.

The soil samples representing the predominant rice growing tracts of Kattakulam, Nachikulam, Sukkampatti and South Irumbadi villages of Vadipatti block of Madurai district of Tamil Nadu with high available status of phosphorus ranging above $22 \mathrm{kgha}^{-1}$ and Viralipatti, Karupatti, Manickampatti, Kacchakatti and Irumbadi villages were categorized as low available phosphorus region with the available $\mathrm{P}$ status ranging below $11 \mathrm{kgha}^{-1}$ were chosen to conduct the incubation study.

\section{Preparation of soil samples for analysis}

The soil samples collected from the above location were processed and used for laboratory incubation studies. The samples were air dried, powdered and sieved through $2.0 \mathrm{~mm}$ sieve for the analysis of basic parameters like $\mathrm{pH}$, electrical conductivity and available nutrients like nitrogen, phosphorus and potassium. For estimating organic carbon the samples were sieved through $0.5 \mathrm{~mm}$ sieve separately by adopting standard procedures.

\section{Laboratory incubation study to evaluate the $P$ release pattern}

Two hundred grams of soil was used for each experimental unit and the incubation was carried out in $500 \mathrm{ml}$ plastic storage containers. Each treatment combination was incubated maintaining the maximum moisture content at field capacity (21 \% gravimetrically) under laboratory conditions. Soil samples were drawn at weekly intervals and analysed for different inorganic $P$ fractions like Saloid-P, Al-P, Fe-P, Red-P and $\mathrm{Ca}-\mathrm{P}$ were analysed during the pre and post incubation period. 
The treatments were imposed based on the fertiliser recommendation viz., 150:50:50 Kg $\mathrm{N}, \mathrm{P}_{2} \mathrm{O}_{5}, \mathrm{~K}_{2} \mathrm{O}$ ha $^{-1}$, Mussoorie rock phosphate @ $224 \mathrm{~kg} \mathrm{ha}^{-1}$, farm yard manure @ 12.5 tonnes $\mathrm{ha}^{-1}$ and phosphate solubilising bacteria (Lignite based phosphate solubilizing bacterium, Bacillus megaterium var. Phosphaticum PSB-1) @ $2 \mathrm{~kg} \mathrm{ha}^{-1}$ in a Completely Randomized Design (CRD) replicated thrice with the treatment details as furnished below. $\mathrm{T}_{1}$-Complex fertiliser source (20:20:0); $\quad \mathrm{T}_{2}$-Complex fertiliser source (20:20:0) + Phosphorus solubilizing bacteria; $\mathrm{T}_{3}$-Mussoorie rock phosphate + Phosphorus solubilizing bacteria; $\mathrm{T}_{4}$-Farm yard manure + Straight fertiliser source (Single super phosphate); T5-Straight fertiliser source (Single super phosphate); $\mathrm{T}_{6}$-Control (No fertiliser).

\section{Results and Discussion}

Effect of treatments on the added $\mathrm{P}$ into different inorganic fractions in the soils of low available $\mathrm{P}$ status are furnished in the table 3 and 4.

Major portion of the total $\mathrm{P}$ in soil happens to be inorganic P. A perusal data from the tables 3 and 4, revealed that appreciable build-up of total inorganic $\mathrm{P}$ due to the addition of various forms of fertilisers. The inorganic $P$ content was higher in the treatments which received one of the chemical fertilisers compared to the untreated control.

In the soils of low available $\mathrm{P}$ status, higher status of Fe-P (192 $\mathrm{mg} \mathrm{kg}^{-1}$ ), Saloid-P (47.0 $\left.\mathrm{mg} \mathrm{kg}{ }^{-1}\right)$, and Red-P (25.2 $\left.\mathrm{mg} \mathrm{kg}^{-1}\right)$ fractions were noted in Single Super Phosphate and Farm Yard Manure (T4) treated soils and with regard to the Al-P (144 $\mathrm{mg} \mathrm{kg}^{-1}$ ), and Ca-P (112 $\mathrm{mg} \mathrm{kg}^{-1}$ ) reaction, Mussoorie Rock Phosphate along with PSB and complex fertiliser treated soils registered the maximum $P$ release, respectively.

Table.1 Details of predominant rice growing villages of Vadipatti block of Madurai district

\begin{tabular}{|c|c|c|c|c|c|}
\hline 1. & Aandipatti & 10. & Kattakulam & 19. & Poochampatti \\
\hline 2. & Bodhinayackanpatti & 11. & Karupatti & 20. & Ramayanpatti \\
\hline 3. & Cheminipatti & 12. & Kulasekarankottai & 21. & Sukkampatti \\
\hline 4. & Chinnamanayackanpatti & 13. & Kutladampatti & 22. & Thatthampatti \\
\hline 5. & Chitthalankudi & 14. & Kuruvithurai & 23. & Thiruvedagam \\
\hline 6. & C.Pudhur & 15. & Mannadimangalm & 24. & Thumbichampatti \\
\hline 7. & Irumbadi & 16. & Manickampatti & 25. & T.V.Nallur \\
\hline 8. & Kacchakatti & 17. & Naachikulam & 26. & Viralipatti \\
\hline 9. & Kaadupatti & 18. & Nedungulam, & & \\
\hline
\end{tabular}

Table.2 Details of location of soils of low and high P availability

\begin{tabular}{|l|l|l|}
\hline S.No & Low $\mathbf{P}$ available regions & High $\mathbf{P}$ available regions \\
\hline 1. & Viralipatti & Kattakulam \\
\hline 2. & Karupatti & Nachikulam \\
\hline 3. & Manickampatti & Kattakulam West \\
\hline 4. & Kacchakatti & Sukkampatti \\
\hline 5. & Irumbadi & South Irumbadi \\
\hline
\end{tabular}


Table. 3 Release pattern of inorganic P fractions $\left(\mathrm{mg} \mathrm{kg}^{-1}\right)$ in soils of low available $\mathrm{P}$

\begin{tabular}{|c|c|c|c|c|c|c|c|c|c|c|c|}
\hline \multirow[t]{2}{*}{ S.No. } & \multirow[t]{2}{*}{ Treatments } & \multicolumn{2}{|c|}{ Saloid P } & \multicolumn{2}{|c|}{ Al- $\mathbf{P}$} & \multicolumn{2}{|c|}{ Fe-P } & \multicolumn{2}{|c|}{ Red-P } & \multicolumn{2}{|c|}{ Ca-P } \\
\hline & & $\begin{array}{c}\text { Pre } \\
\text { incubation }\end{array}$ & $\begin{array}{c}\text { Post } \\
\text { incubation }\end{array}$ & $\begin{array}{c}\text { Pre } \\
\text { incubation }\end{array}$ & $\begin{array}{c}\text { Post } \\
\text { incubation }\end{array}$ & $\begin{array}{c}\text { Pre } \\
\text { incubation }\end{array}$ & $\begin{array}{c}\text { Post } \\
\text { incubation }\end{array}$ & $\begin{array}{c}\text { Pre } \\
\text { incubation }\end{array}$ & $\begin{array}{c}\text { Post } \\
\text { incubation }\end{array}$ & $\begin{array}{c}\text { Pre } \\
\text { incubation }\end{array}$ & $\begin{array}{c}\text { Post } \\
\text { incubation }\end{array}$ \\
\hline \multirow[t]{6}{*}{$\mathrm{S} 1$} & $\mathrm{~T} 1$ & \multirow[t]{6}{*}{13} & 31 & \multirow[t]{6}{*}{91} & 125 & \multirow[t]{6}{*}{132} & 165 & \multirow[t]{6}{*}{11} & 13 & \multirow[t]{6}{*}{73} & 108 \\
\hline & $\mathrm{T} 2$ & & 43 & & 132 & & 178 & & 20 & & 110 \\
\hline & T3 & & 39 & & 146 & & 189 & & 17 & & 113 \\
\hline & $\mathrm{T} 4$ & & 48 & & 135 & & 192 & & 25 & & 108 \\
\hline & T5 & & 20 & & 101 & & 173 & & 16 & & 100 \\
\hline & T6 & & 16 & & 98 & & 167 & & 11 & & 98 \\
\hline \multirow[t]{6}{*}{$\mathrm{S} 2$} & $\mathrm{~T} 1$ & \multirow[t]{6}{*}{14} & 32 & \multirow[t]{6}{*}{90} & 128 & \multirow[t]{6}{*}{133} & 165 & \multirow[t]{6}{*}{12} & 19 & \multirow[t]{6}{*}{89} & 111 \\
\hline & $\mathrm{T} 2$ & & 45 & & 129 & & 172 & & 20 & & 105 \\
\hline & T3 & & 36 & & 138 & & 183 & & 17 & & 110 \\
\hline & $\mathrm{T} 4$ & & 49 & & 136 & & 194 & & 23 & & 117 \\
\hline & T5 & & 21 & & 102 & & 171 & & 20 & & 98 \\
\hline & T6 & & 15 & & 97 & & 163 & & 13 & & 95 \\
\hline \multirow[t]{6}{*}{ S3 } & $\mathrm{T} 1$ & \multirow[t]{6}{*}{13} & 38 & \multirow[t]{6}{*}{89} & 121 & \multirow[t]{6}{*}{135} & 166 & \multirow[t]{6}{*}{14} & 15 & \multirow[t]{6}{*}{95} & 111 \\
\hline & $\mathrm{T} 2$ & & 47 & & 125 & & 177 & & 25 & & 105 \\
\hline & T3 & & 41 & & 142 & & 181 & & 20 & & 110 \\
\hline & $\mathrm{T} 4$ & & 53 & & 138 & & 183 & & 26 & & 117 \\
\hline & T5 & & 26 & & 101 & & 175 & & 14 & & 98 \\
\hline & T6 & & 19 & & 99 & & 166 & & 17 & & 95 \\
\hline \multirow[t]{6}{*}{$\mathrm{S} 4$} & $\mathrm{~T} 1$ & \multirow[t]{6}{*}{16} & 33 & 95 & 126 & 133 & 161 & 10 & 19 & 95 & 110 \\
\hline & $\mathrm{T} 2$ & & 45 & & 138 & & 173 & & 22 & & 109 \\
\hline & T3 & & 42 & & 149 & & 187 & & 18 & & 108 \\
\hline & $\mathrm{T} 4$ & & 33 & & 138 & & 195 & & 27 & & 106 \\
\hline & T5 & & 25 & & 103 & & 176 & & 21 & & 105 \\
\hline & T6 & & 19 & & 105 & & 162 & & 18 & & 100 \\
\hline S5 & $\mathrm{T} 1$ & 18 & 37 & 95 & 129 & 135 & 166 & 9 & 16 & 98 & 115 \\
\hline & T2 & & 47 & & 132 & & 174 & & 23 & & 116 \\
\hline & T3 & & 39 & & 146 & & 189 & & 17 & & 114 \\
\hline & $\mathrm{T} 4$ & & 51 & & 139 & & 193 & & 25 & & 112 \\
\hline & T5 & & 25 & & 104 & & 171 & & 20 & & 110 \\
\hline & T6 & & 18 & & 102 & & 165 & & 15 & & 102 \\
\hline
\end{tabular}


Table 3. (Contd..)

\begin{tabular}{|c|c|c|c|c|c|c|}
\hline \multicolumn{2}{|c|}{ Mean Table } & Saloid- P & Al-P & Fe-P & Red -P & Ca-P \\
\hline \multicolumn{2}{|c|}{ Grand Mean } & 35.2 & 123 & 175 & 19.1 & 107 \\
\hline \multicolumn{2}{|c|}{$\mathrm{S} 1$} & 33.2 & 122 & 177 & 17.1 & 106 \\
\hline \multicolumn{2}{|c|}{$\mathrm{S} 2$} & 34.9 & 121 & 174 & 17.8 & 106 \\
\hline \multicolumn{2}{|c|}{ S3 } & 38.1 & 121 & 174 & 20.3 & 108 \\
\hline \multicolumn{2}{|c|}{$\mathrm{S} 4$} & 33.8 & 126 & 177 & 20.8 & 106 \\
\hline \multicolumn{2}{|c|}{ S5 } & 36.2 & 125 & 176 & 19.3 & 111 \\
\hline \multicolumn{2}{|c|}{$\mathrm{T} 1$} & 35.2 & 126 & 165 & 21.9 & 112 \\
\hline \multicolumn{2}{|c|}{$\mathrm{T} 2$} & 45.8 & 130 & 175 & 15.3 & 111 \\
\hline \multicolumn{2}{|c|}{ T3 } & 41.5 & 144 & 186 & 17.8 & 111 \\
\hline \multicolumn{2}{|c|}{$\mathrm{T} 4$} & 47.0 & 137 & 192 & 25.2 & 110 \\
\hline \multicolumn{2}{|c|}{ T5 } & 24.0 & 102 & 171 & 19.2 & 102 \\
\hline \multicolumn{2}{|c|}{ T6 } & 18.2 & 100 & 163 & 14.8 & 98.4 \\
\hline \multirow[t]{2}{*}{$\mathbf{S}$} & SED & 1.08 & 0.33 & 0.37 & 0.16 & 0.33 \\
\hline & $\mathrm{CD}(0.05)$ & 2.16 & 0.66 & 0.74 & 0.32 & 0.66 \\
\hline \multirow[t]{2}{*}{$\mathbf{T}$} & SED & 1.18 & 0.36 & 0.40 & 0.17 & 0.36 \\
\hline & $\mathrm{CD}(0.05)$ & 2.36 & 0.73 & 0.81 & 0.35 & 0.73 \\
\hline \multirow[t]{2}{*}{$\mathbf{S} \times \mathbf{T}$} & SED & 2.64 & 0.81 & 0.91 & 0.39 & 0.81 \\
\hline & $\mathrm{CD}(0.05)$ & 5.29 & 1.63 & 1.83 & 0.79 & 1.63 \\
\hline
\end{tabular}


Table.4 Release pattern of inorganic $\mathrm{P}$ fractions $\left(\mathrm{mg} \mathrm{kg}^{-1}\right)$ in soils of high available $\mathrm{P}$

\begin{tabular}{|c|c|c|c|c|c|c|c|c|c|c|c|}
\hline \multirow{2}{*}{$\begin{array}{c}\text { S. } \\
\text { No. }\end{array}$} & \multirow[t]{2}{*}{ Treatments } & \multicolumn{2}{|c|}{ Saloid P } & \multicolumn{2}{|c|}{ Al- $\mathbf{P}$} & \multicolumn{2}{|c|}{ Fe-P } & \multicolumn{2}{|c|}{ Red-P } & \multicolumn{2}{|c|}{ Ca-P } \\
\hline & & $\begin{array}{c}\text { Pre- } \\
\text { incubation }\end{array}$ & $\begin{array}{c}\text { Post - } \\
\text { incubation }\end{array}$ & $\begin{array}{c}\text { Pre- } \\
\text { incubation }\end{array}$ & $\begin{array}{c}\text { Post- } \\
\text { incubation }\end{array}$ & $\begin{array}{c}\text { Pre- } \\
\text { incubation }\end{array}$ & $\begin{array}{c}\text { Post- } \\
\text { incubation }\end{array}$ & $\begin{array}{c}\text { Pre- } \\
\text { incubation }\end{array}$ & $\begin{array}{c}\text { Post- } \\
\text { incubation }\end{array}$ & $\begin{array}{c}\text { Pre- } \\
\text { incubation }\end{array}$ & $\begin{array}{c}\text { Post- } \\
\text { incubation }\end{array}$ \\
\hline \multirow[t]{6}{*}{ S1 } & $\mathrm{T} 1$ & \multirow[t]{6}{*}{18} & 43 & \multirow[t]{6}{*}{99} & 136 & \multirow[t]{6}{*}{138} & 179 & \multirow[t]{6}{*}{18} & 25 & \multirow[t]{6}{*}{86} & 110 \\
\hline & $\mathrm{T} 2$ & & 50 & & 143 & & 185 & & 22 & & 112 \\
\hline & T3 & & 48 & & 158 & & 192 & & 29 & & 115 \\
\hline & $\mathrm{T} 4$ & & 55 & & 141 & & 201 & & 30 & & 110 \\
\hline & $\mathrm{T} 5$ & & 21 & & 122 & & 186 & & 24 & & 120 \\
\hline & T6 & & 19 & & 105 & & 173 & & 23 & & 112 \\
\hline \multirow[t]{6}{*}{$\mathrm{S} 2$} & $\mathrm{~T} 1$ & \multirow[t]{6}{*}{18} & 35 & \multirow[t]{6}{*}{98} & 136 & \multirow[t]{6}{*}{142} & 171 & \multirow[t]{6}{*}{21} & 26 & \multirow[t]{6}{*}{88} & 116 \\
\hline & $\mathrm{T} 2$ & & 48 & & 139 & & 182 & & 18 & & 109 \\
\hline & $\mathrm{T} 3$ & & 49 & & 141 & & 194 & & 24 & & 117 \\
\hline & $\mathrm{T} 4$ & & 67 & & 140 & & 179 & & 27 & & 121 \\
\hline & $\mathrm{T} 5$ & & 38 & & 120 & & 178 & & 20 & & 108 \\
\hline & T6 & & 17 & & 105 & & 179 & & 25 & & 105 \\
\hline \multirow[t]{6}{*}{$\mathrm{S} 3$} & T1 & \multirow[t]{6}{*}{19} & 49 & \multirow[t]{6}{*}{97} & 131 & \multirow[t]{6}{*}{139} & 177 & 21 & 29 & \multirow[t]{6}{*}{98} & 125 \\
\hline & $\mathrm{T} 2$ & & 53 & & 137 & & 183 & & 20 & & 126 \\
\hline & $\mathrm{T} 3$ & & 48 & & 156 & & 195 & & 25 & & 120 \\
\hline & $\mathrm{T} 4$ & & 69 & & 147 & & 197 & & 30 & & 119 \\
\hline & $\mathrm{T} 5$ & & 35 & & 110 & & 184 & & 24 & & 118 \\
\hline & T6 & & 25 & & 107 & & 170 & & 26 & & 109 \\
\hline \multirow[t]{6}{*}{$\mathrm{S} 4$} & T1 & \multirow[t]{6}{*}{23} & 39 & \multirow[t]{6}{*}{102} & 129 & 141 & 169 & 20 & 29 & 105 & 125 \\
\hline & $\mathrm{T} 2$ & & 56 & & 139 & & 179 & & 27 & & 123 \\
\hline & T3 & & 61 & & 157 & & 196 & & 26 & & 121 \\
\hline & $\mathrm{T} 4$ & & 35 & & 147 & & 210 & & 34 & & 120 \\
\hline & T5 & & 29 & & 124 & & 183 & & 25 & & 119 \\
\hline & T6 & & 21 & & 112 & & 173 & & 27 & & 102 \\
\hline S5 & $\mathrm{T} 1$ & 25 & 39 & 105 & 139 & 142 & 179 & 22 & 29 & 110 & 125 \\
\hline & $\mathrm{T} 2$ & & 51 & & 141 & & 185 & & 22 & & 124 \\
\hline & T3 & & 53 & & 153 & & 209 & & 26 & & 123 \\
\hline & $\mathrm{T} 4$ & & 69 & & 151 & & 180 & & 31 & & 121 \\
\hline & T5 & & 41 & & 119 & & 183 & & 22 & & 120 \\
\hline & T6 & & 19 & & 113 & & 172 & & 29 & & 118 \\
\hline
\end{tabular}


Table 4. (Contd...)

\begin{tabular}{|c|c|c|c|c|c|c|}
\hline \multicolumn{2}{|c|}{ Mean Table } & Saloid- P & Al-P & Fe-P & Red -P & Ca-P \\
\hline \multicolumn{2}{|c|}{ Grand Mean } & 44.4 & 133 & 184 & 25.8 & 116 \\
\hline \multicolumn{2}{|c|}{ S1 } & 41.8 & 134 & 186 & 25.5 & 113 \\
\hline \multicolumn{2}{|c|}{ S2 } & 43.8 & 130 & 180 & 23.3 & 112 \\
\hline \multicolumn{2}{|c|}{ S3 } & 44.0 & 131 & 184 & 25.6 & 119 \\
\hline \multicolumn{2}{|c|}{ S4 } & 43.3 & 134 & 184 & 27.9 & 118 \\
\hline \multicolumn{2}{|c|}{ S5 } & 49.1 & 136 & 184 & 26.4 & 121 \\
\hline \multicolumn{2}{|c|}{$\mathrm{T} 1$} & 45.2 & 134 & 173 & 27.6 & 120 \\
\hline \multicolumn{2}{|c|}{$\mathrm{T} 2$} & 56.6 & 139 & 182 & 23.0 & 118 \\
\hline \multicolumn{2}{|c|}{ T3 } & 46.6 & 152 & 197 & 25.9 & 119 \\
\hline \multicolumn{2}{|c|}{$\mathrm{T} 4$} & 64.6 & 145 & 193 & 30.4 & 118 \\
\hline \multicolumn{2}{|c|}{ T5 } & 33.2 & 119 & 182 & 26.0 & 117 \\
\hline \multicolumn{2}{|c|}{ T6 } & 20.4 & 108 & 174 & 21.8 & 109 \\
\hline \multirow[t]{2}{*}{$\mathbf{S}$} & SED & 0.32 & 0.34 & 1.53 & 0.24 & 0.33 \\
\hline & CD (0.05) & 0.65 & 0.69 & 3.08 & 0.48 & 0.66 \\
\hline \multirow[t]{2}{*}{$\mathbf{T}$} & SED & 0.35 & 0.38 & 1.68 & 0.26 & 0.36 \\
\hline & CD (0.05) & 0.71 & 0.76 & 3.37 & 0.52 & 0.73 \\
\hline \multirow[t]{2}{*}{$\mathbf{S} \times \mathbf{T}$} & SED & 0.79 & 0.85 & 3.77 & 0.58 & 0.81 \\
\hline & CD (0.05) & 1.59 & 1.70 & 7.54 & 1.17 & 1.63 \\
\hline
\end{tabular}


In the soils of high available $\mathrm{P}$ status, Saloid$\mathrm{P}\left(64 \mathrm{mg} \mathrm{kg}^{-1}\right)$ and Red -P (30.4 $\mathrm{mg} \mathrm{kg}^{-1}$ ) were higher in the SSP and FYM treated soils, Al-P (152 $\mathrm{mg} \mathrm{kg}^{-1}$ ) and Fe-P (197 $\mathrm{mg} \mathrm{kg}^{-1}$ ) were higher in the MRP and PSB treated soils whereas Ca-P (120 mg kg-1) was the maximum in the complex fertiliser source treated soils.

Among the inorganic $\mathrm{P}$ fractions in the soil, $\mathrm{Fe}-\mathrm{P}$ was the most predominant fraction followed by Al-P, Ca-P, Saloid-P and Red-P fractions. The higher status of $\mathrm{P}$ fractions in the fertiliser treated soils might be attributed to the better conservation of $\mathrm{P}$ applied through fertilisers in these treatments. Similar results were reported by Mahapatra and Patrick (1971) and Ivanov (1975) who attributed this increase to the addition of $\mathrm{P}$ through fertilisers.

The distribution pattern of inorganic fractions at the pre and post incubation periods in the soils followed the pattern of Fe-P (38 and $36 \%)>\mathrm{Al}-\mathrm{P}(26.8$ and $26.4 \%)>\mathrm{Ca}-\mathrm{P}(23.3$ and $23.2 \%)>$ Saloid-P (7.5 and $8.8 \%)>$ Red-P (4 and $5 \%$ ) similar to the inherent distribution of these fractions in the soil indicating that the applied $\mathrm{P}$ has been transformed into all the $\mathrm{P}$ fractions of Al-P, $\mathrm{Fe}-\mathrm{P}$ and $\mathrm{Ca}-\mathrm{P}$ due to the neutral $\mathrm{pH}$ of the soil. This was in accordance with the report of Jose (1973) who studied the transformation of added water soluble $\mathrm{P}$ in neutral to slightly alkaline soils of South India and concluded that the transformation of added $\mathrm{P}$ was in corroboration with the initial distribution pattern of the inorganic $\mathrm{P}$ fractions in the soils. Most of the water soluble $\mathrm{P}$ added to the soil was transformed into insoluble inorganic forms depending mainly upon the chemical characteristics of soil (Bell and Black, 1970 Mandal and Das, 1970). The results further confirmed that all the $\mathrm{P}$ fractions were higher at post incubation period than the initial stage of incubation indicating that the applied $\mathrm{P}$ has got transformed into all the $\mathrm{P}$ inorganic fractions. This was corroborated with the results of Prasad and Power (1997).

In conclusion, the distribution pattern of inorganic fractions at the pre and post incubation period in the soils followed the pattern of Fe-P > Al-P >Ca-P > Saloid-P > Red-P similar to the inherent distribution of these fractions in the soil indicating that the applied $\mathrm{P}$ has been transformed into all inorganic $\mathrm{P}$ fractions. The release pattern of soil treated with P fertilisers was significantly higher than the untreated control and continued to decrease gradually during the course of incubation period (1 - 60 days).

\section{Acknowledgement}

M/s Rhastriya Chemicals and Fertilizers Limited, Mumbai and Department of Soils and Environment, Agricultural College and research Institute, Madurai, Tamil Nadu.

\section{References}

Bell, B.C. and Black, C.A. 1970. Comparison of methods for identifying crystalline phosphate produced by interaction of orthophosphate fertilizers with soils. Soil Sci. Soc. America Proceedings, 34: 579-582.

Dange, S.S., Pushpalata, C., Bhosale, M., Dipti, S., Waghdhare, I. and S.R. Patil. 2008. In vivo effects of phosphorus sources with and without FYM and biofertilizers on availability of phosphorus in calcareous black soil 3(1): 79.

De Datta, S.K. and Mikkelson, D.S. 1985. Potassium nutrition of rice. In: Potassium in Agriculture (Eds.) Munson, R.D., Summer M.E. and Bishop, W.D., Madison, 665-699.

Ivanov, P. 1975. Reaction of the water soluble phosphorus in chernozem and 
grey forest soils. Pochvoza Agrokhim., 10: 30-34.

Jose, A.I. 1973. Studies on soil phosphorus in the South Indian soils of neutral to alkaline reaction, Ph.D. Thesis, Tamil Nadu Agricultural University, India.

Mahapatra, I.C. and Patrick, W.H. 1971. Evaluation of phosphate fertility in waterlogged soils. International symposium on soil fertility evaluation proceedings, New Delhi, 1: 53-61.

Mandal, L.N. and Das, R.K. 1970.
Transformation of applied water soluble phosphate in acidic lowland, rice soils. Soil Sci.,107: 263-267.

Prasad, R. and Power, J.F. 1997. Soil fertility management for sustainable agriculture. CRC, Lewis, Boca Raton, NY, 356.

Tandon, H.L.S. 1987. Phosphorus research and agricultural production in India. Fertiliser Development and Consultation Organisation, New Delhi, India, 160.

\section{How to cite this article:}

Jemila, C., B. Bakiyathu Saliha and Udayakumar, S. 2017. A Study on the Distribution of Inorganic P Fractions in Soils of Low and High Available Phosphorus through a Laboratory Incubation Experiment. Int.J.Curr.Microbiol.App.Sci. 6(3): 929-937. doi: https://doi.org/10.20546/ijcmas.2017.603.110 